\title{
Cattlemen's Choice of Status in the Northern Pantanal of Brazil as a Social Process of Cultural Transmission
}

\author{
André L. Ribeiro Lacerda \\ Department of Sociology and Political Science, Federal University of Mato Grosso, Brazil
}

Copyright $\bigcirc 2017$ by authors, all rights reserved. Authors agree that this article remains permanently open access under the terms of the Creative Commons Attribution License 4.0 International License

\begin{abstract}
This study aims to present the changes identified within the structure of the status of Pantanal cattlemen in Poconé - MT which help us understand why the young generation of Pantanal cattlemen see cattle breeding in the Pantanal as a complementary economic activity and why most of their offspring are not interested in it. The work defends the general hypothesis that the Pantanal cattleman's choice of status used to be influenced by his family along paths suggested by the cultural transmission theory in agreement with the mechanism of direct vertical socialization, although this has been changing because: (h1) changes in the social structure drawn from the status of Pantanal cattlemen (status set) do not favor investing in the occupational status of Pantanal cattlemen; (2) those who choose the social role of a Pantanal cattleman do so considering it a secondary, complementary economic activity and which minimizes conflicts with the role of their main occupational status. Data collected from cattlemen in $2015(n=29)$ sustain the two hypotheses.
\end{abstract}

Keywords Cultural Transmission, Pantanal Cattlemen, Status, Family

\section{Introduction}

Culture can be defined as the set of the set of customs and technologies that have played and continue to play an essential role in the evolution of human behaviour [1]. Culture is what we learn from others and, especially, from our ancestors. Therefore, cultural heritage is the transmission of information from one generation to another.

One way of transmitting culture is the one that takes place within the family, known as vertical socializing [1-4]. It assumes that: (1) parents act consciously when socializing their offspring along particular cultural traits; (2) children acquire preferences by imitating individual actions from the family, although mediated by the social environment. The process of socialization is here seen as the result of resources intentionally invested by individuals and institutions. Parents devote energy, money, and other resources when choosing the kind of school and social setting for their children [4].

According to Bisin and Verdier [4], beliefs, preferences and norms that guide human behavior are partially formed as a product of hereditary genetic traits and partially transmitted from one generation to the next and acquired through learning and other forms of social interaction. Therefore, cultural transmission plays an important role in the formation of some traits of preference, such as the occupational choice.

Based on Bisin and Verdier's [4] concept of cultural transmission, it can be said that this article focuses on a type of intergenerational transmission of culture carried out within the family: the choice of cattleman status in the Pantanal in Poconé-MT.

Being a cattleman in the Pantanal of Mato Grosso involves the extra challenge of managing something that is inexistent on the horizon of dryland cattlemen: the water cycle. During the flooding and a great part of the ebb tide, cattlemen need to move cattle to higher lands. If their property has hummocks, their job turns out to be easier; otherwise, if they cannot count on areas that are not flooded during the Pantanal high water season, they have to rent land from another property and take their cattle there. This involves extra expenses, considering that the flood season results in an increased loss of livestock heads and a diminished lifespan of fences, which will need to be rebuilt. At the time when properties and herds used to be large, those costs were offset by other advantages and being a Pantanal cattleman used to be an assigned status as this status was inherited from the family, generally from father to son. However, things have changed and many of those advantages have faded.

This study aims to present the changes identified within the structure of the status of Pantanal cattlemen in Poconé MT which help us understand why the young generation of Pantanal cattlemen see cattle breeding in the Pantanal as a complementary economic activity and why most of their offspring are not interested in it. The work defends the general hypothesis that the Pantanal cattleman's choice of status used to be influenced by his family along paths suggested by the cultural transmission theory in agreement 
with the mechanism of direct vertical socialization, although this has been changing because: (h1) changes in the social structure drawn from the status of Pantanal cattlemen (status set) do not favor investing in the occupational status of Pantanal cattlemen; (2) those who choose the social role of a Pantanal cattleman do so considering it a secondary, complementary economic activity and which minimizes conflicts with the role of their main occupational status. Data collected from cattlemen in $2015(\mathrm{n}=29)$ sustain the two hypotheses.

\section{Theoretical Foundation}

The issue of choosing the occupational status in advanced industrialized societies is important from the sociological point of view because it involves the decision to invest in the acquired status, which theoretically stipulates time and energy availability to be invested in the other statuses whether they be assigned or acquired. According to Hopcroft and Whitmeyer [5], investment in occupational status in advanced industrialized societies involves long years of educational socialization and occupational training.

The changes identified in the status of the Pantanal cattlemen suggest changes in the social process of choosing an occupation, which used to be an essentially assigned social status and that now, considering the loss of references that used to primarily turn it into a process linked to the family, it stops being a process with the strong characteristics of an assigned status.

It is not a question of denying the family's influence on the choice of the occupational status of their children, but to explore, theoretically and empirically, the contrast that exists in relation to various other occupational areas where work is no longer an inherited activity, that is, where the transfer of an enterprise's control does not occur between members of the same family, as is still done in agriculture.

The issue of choosing an occupational status among the Pantanal cattlemen can be seen as a social process of cultural transmission [1-4]. The son of a Pantanal cattleman in Poconé has three options: he may continue with the family's tradition and choose to be a full-time cattleman he can choose being a cattleman in his free time while he has some other occupation, or he might choose another occupation and give up his link with cattle breeding.

The way Bisin and Verdier [4] frame the role of cultural transmission in the formation of some traits of preference such as the choice of occupational status, one may ask: what differences exist in the mechanism of vertical socialization within the family between occupational statuses which constitute family businesses and other acquired statuses? Why do some parents choose to invest more time and energy in their children than others? Why do some Pantanal cattlemen's sons choose to invest in their parents' occupation and other children choose otherwise?

Several studies within the evolutionary perspective, as stated by Hopcroft and Whitmeyer [5] sustain that the acquisition of social status facilitates reproduction, particularly in pre-industrial societies. A great part of sociological research supports the hypothesis that the search for status is a means of obtaining future resources [6-8], that is human beings strive to have access to intangible assets as well. This idea views human beings as social actors who "rationally" pursue status as a skill symbol and as a means of obtaining resources [8], unlike the evolutionary psychology hypothesis which claims that status may not be a means to an end, but an end in itself $[9,10]$.

The case of the Pantanal cattlemen here presented provides a test for the cultural transmission theory considering that this transmission is seen as the result of interactions between socializing decisions made within the family [4]. .

The general idea is that the presented data reflect a context of changes between considerably different social situations. On the one hand, there was a past where the occupational choice was basically made by the family; Sons and daughters would naturally inherit a "piece" of the farm and, directly or indirectly, became cattle breeders. On the other hand, considering the present reduction of the size of the inherited lands, the social condition of cattlemen is no longer attractive and the parents themselves discourage investment in their occupational status.

The social situation in which an occupational status is no longer attributed and where the social actors stop invoking family tradition as the reason for their choice seems to be a borderline situation in the choice between the assigned and acquired status, between the pursuit of status as something rational to gain power and the pursuit of status as an end in itself. It also allows rendering problematic the influence that the social actor's attributed statuses have on the choice of the status that he acquires in the occupational structure. This question was first framed by Blau and Duncan [11] and can be assessed according to the suggestions of the cultural transmission theory [2-4].

The area of wetland in Mato Grosso, known as the Northern Pantanal, includes seven cities: Cáceres, Poconé, Santo Antônio do Leverger, Barão de Melgaço, Itiquira, Nossa Senhora do Livramento and Lambari D'oeste [12]. Because they are closer to Cuiabá, some of these cities develop closer relationships in terms of flow of people and commerce. This is the case of Poconé, a city with 31,779 inhabitants, located $100 \mathrm{~km}$ from Cuiabá, state capital of Mato Grosso.

For some time, the status of Pantanal cattlemen enjoyed high prestige within the society both in the city of Poconé and in the state of Mato Grosso. Pantanal cattlemen managed to imprint, culturally speaking, a lifestyle known as pantaneiro. This style combined catholic religious values, a social stratification based on a great social inequality where cattlemen held the top position of the social hierarchy, big extensive cattle breeding rural properties where the cattleman's nuclear family and their employees lived, and 
low productivity as cattle was raised loose and the technologies used were low skilled.

This social structure, here understood as the set of social statuses linked to the status of Pantanal cattlemen and the cultural systems to which they used to be and are still connected $[13,14]$, has undergone transformations.

The political and economic reorganization now taking place in Poconé is quite noticeable. It is a process caused by the loss of social prestige faced by the Pantanal cattlemen who used to be part of the political and economic elite. One of the highlights in the city's annual calendar used to be saint festivities organized and funded by the wetland cattlemen, where they reaffirmed their social prestige. Although those celebrations still take place, they do not have the economic weight and the social importance of old.

According to reports from wetland cattlemen in Poconé, they used to go through three different annual situations in the Pantanal water cycle: the dry, the ebbing and the flooding seasons. The dry season would take place between July and December; from December to July the area would flood and then the ebbing season would come from April through June or July.

The life of wetland cattlemen was clearly divided into two yearly periods. Cattlemen would spend the dry season at the farm and work hard from July through December. During the flooding season and most of the ebbing season they would live in the city of Poconé. It was at this time that the saint festivities took place and promoted intense social activity.

This lifestyle has changed. The Pantanal cattlemen no longer have the economic power they used to have, neither do they participate in the politics of the district of Poconé and of the state as they used to when several wetland cattlemen occupied posts in the state and municipal administration.

The macrosociological changes seem to make themselves felt in the status of the wetland cattlemen, formerly seen as a lifestyle symbol. If the status of the Pantanal cattlemen was basically inherited and if there was a set of social and economic variables that made the choice advantageous because of the economic and political power and prestige it provided, these advantages do not seem to exist anymore, and many wetland cattlemen will not have a successor in the family. This is what primary data collected from wetland cattlemen, members of the farmers' union of Poconé have shown.

\section{Methods}

One of the greatest challenges in this research was finding the Pantanal cattlemen. Many farms are in the lower Pantanal and are only accessible by airplane. The Pantanal is a mostly flooded area covering $250,000 \mathrm{~km}$ in length at an average altitude of $100 \mathrm{~m}$ above sea level. It is in the south of the state of Mato Grosso and northeast of Mato
Grosso do Sul in Brazil, also occupying areas in Paraguay and Bolivia.

The collection of secondary data also proved to be difficult. For example, official data on the number of rural properties in the wetland of Poconé are inconsistent. The INDEA in Poconé reported 557 properties in 2013. INDEA head office in Cuiabá reported 628 properties. The city hall of Poconé has not provided data.

In fact, authorities are aware of the changes that have been taking place, but have no reliable data. This has made the task of drawing a sample a very difficult process, as many properties have been abandoned and others have no cattle; in sum, the number of properties is unknown. One of the possible indicators might be the number of animals vaccinated. It is probable that those properties that do not report vaccination do not own cattle. However, this indicator has been contested by INDEA - Poconé; they state that many farmers, who own a significant number of animals aged up to two years, may not vaccinate every consecutive year.

This study collected data from a subpopulation of cattlemen from the wetland in Poconé: those who are members of the district's farmers union. Although this might not be a representative sample of the universe of cattlemen of the wetland in Poconé, it does represent the wetland cattlemen who are linked to the city of Poconé and are heirs to the lifestyle of the cattlemen who made cattle raising in the wetland an economic activity and a way of life. These cattlemen had part of their annual social life connected with the city of Poconé, where they also lived.

The economic difficulties faced by wetland cattlemen and the growing strictness of inspection by the state department of environment and labor have hindered the task of interviewing them, as cattlemen have become elusive and distrustful. Many of them tend to link the interviews to the work of inspectors and, thus, they either refuse to be interviewed or, if they agree, refuse to provide information such as the size of the property or the number of cattle heads. This kind of resistance does not seem to be unusual [15].

Interviews were carried out along 2015. Due to the difficulties in accessing the wetland, a sample was drawn according to the access roads, a sampling by conglomerates. Four roads of access were identified: Estrada Parque Transpantaneira; Estrada Poconé-Porto Cercado; Estrada do Boqueirão and Rodovia Poconé-Cuiabá. These roads lead to back roads.

According to the INDEA office in Poconé, there are 2113 rural properties in the district; 1556 are on dryland and 557 in the wetland. The farmers' union of Poconé only represents the wetland cattlemen. The dryland cattlemen are not members of a union. The union leadership has registered 130 members, but only less than thirty of them participate in the union's routine activities. Many of the interviewed cattlemen stated that they do not participate in meetings anymore nor did they collaborate with the 
monthly fee. Twenty-nine cattlemen were interviewed, i.e. $22.3 \%$ of the union's population of cattlemen.

\section{Results and Discussion}

Cattlemen classify the wetlands in the district of Poconé as low, middle and high. Most of the rural properties are located in the low wetlands, as shown in Figure 1, where land value is lower and the costs that cattlemen have to face are higher considering they have to deal with more difficulties in accessing their properties and managing the water regime. This is where we found the greatest number of abandoned properties.

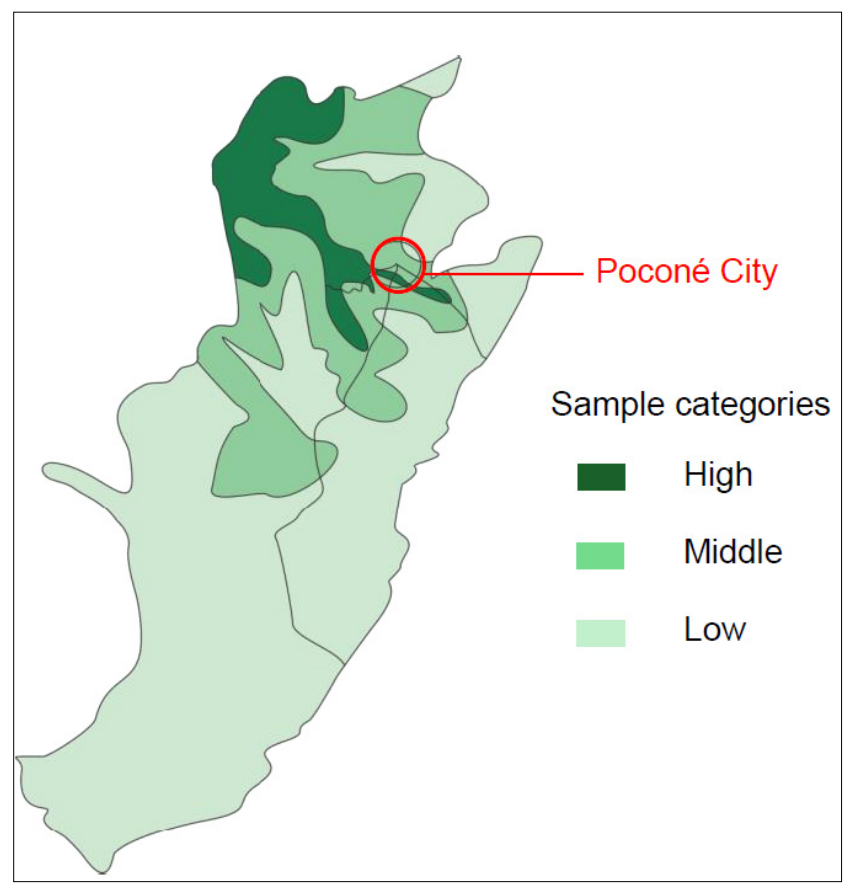

Figure 1. Map of the Pantanal in Poconé District

Most of the rural properties are located in the low wetlands, where land value is lower and the costs that cattlemen have to face are higher considering they have to deal with more difficulties in accessing their properties and managing the water regime. This is where we found the greatest number of abandoned properties.

The interviewed sample is distributed along the wetlands in Poconé according to the Figure 2. More than one third of the sampled individuals own properties in the low wetlands.

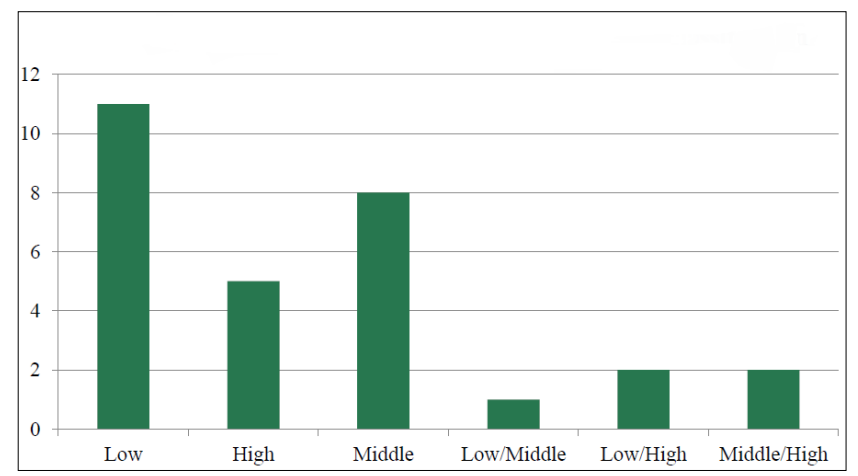

Figure 2. Graph: Property sites according to wetland classification

In relation to the farmers' sex, the occupational status of cattle breeders remains predominantly masculine. Many cattlemen could not be interviewed because they were sick and also because they were not taking proper care of their farms due to their old age. In such cases, even though the farming role was being played by their wives, the latter did not agree to be interviewed. Some stated that farming is men's business.

Data that support hypothesis 1: changes in the social structure drawn from the status of wetland cattlemen (status set) do not favor investing in the occupational status of wetland cattlemen. To test hypothesis 1 , three questions were elaborated: (1) Is it possible to live exclusively off cattle raising in the wetlands nowadays? (2) Where do you live? (3) Children help out in the farm?

Both those that answered yes and those that answered no (question 1) specified the conditions that make cattle raising feasible nowadays in the wetlands: minimum size of the property and minimum number of cattle heads. Their answers can be summed up in Table 1 .

Table 1. Individuals who live exclusively off cattle farming

\begin{tabular}{|c|c|}
\hline Exclusively & Proportion \\
\hline Yes & $20,68 \%$ \\
\hline No & $79,32 \%$ \\
\hline
\end{tabular}

The production structure of cattle breeding in the Pantanal used to be family-based, and carried out extensively in large properties. In this scenario, the help of sons and daughters who would later on inherit their part of the farm was essential.

The fact is that those reported their children did not help out in the farm (Figure 4). Many have small children who are still unable to work. On the other hand, among those who do help, three of them are veterinaries, that is, they engage in activities that are linked to farming. 


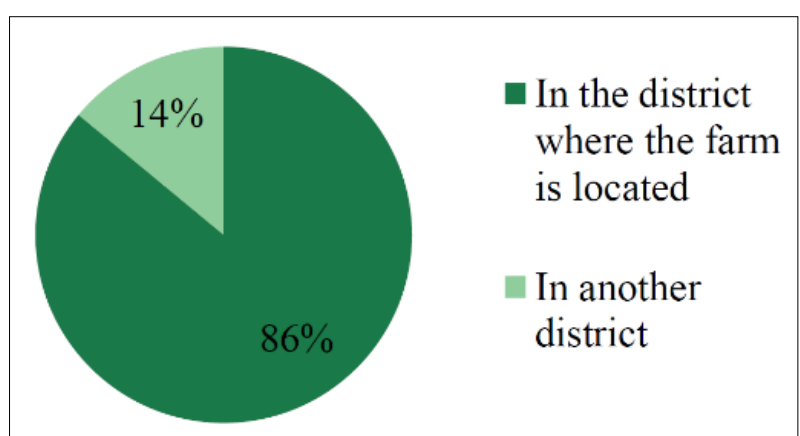

Figure 3. Graph: Where do you live?

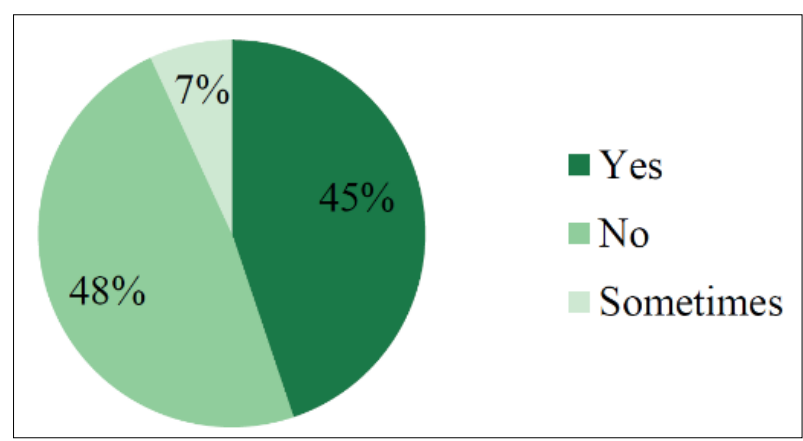

Figure 4. Graph: Children help out in the farm?

Data that support hypothesis 2: those who choose the status of wetland cattlemen do so as a complementary economic activity, a secondary activity and one that minimizes conflicts with their main occupational status.

In relation to developing other economic activities or not, the following questions were asked:

- Do you engage in other economic activities?

- Which is your main economic activity: cattle raising or other?
Among those who reported not developing any other economic activity, some highlighted the fact that they did not do it at that time. In general, they were cattlemen over 60 years of age who had already retired from their secondary activity. In order to know, among those who engage in other economic activities, which were the activities mostly developed, we asked: which is your other economic activity?

We can say that four cattlemen from the new generation were interviewed, although this was done during the early data collection and during the testing phase, and other four agreed to be interviewed. They stand out for clearly defending that cattle raising in the wetlands is only feasible as a complementary economic activity and for criticizing the older generation's insistence in believing that the old extensive wetland cattle raising is still feasible.

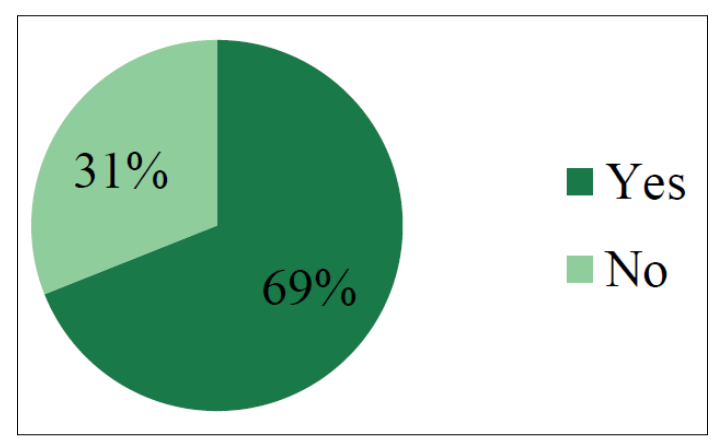

Figure 5. Graph: Do you engage in other economic activities?

Out of the 29 cattlemen interviewed, five of them admitted that cattle breeding was their only income source. Commerce is the most practiced activity by those who are involved in other economic activities (seven cattlemen), all of whom have their business in the city of Poconé. Among the 24 cattlemen involved in other economic activities, only four of them consider cattle breeding as their main economic activity (Figure 6).

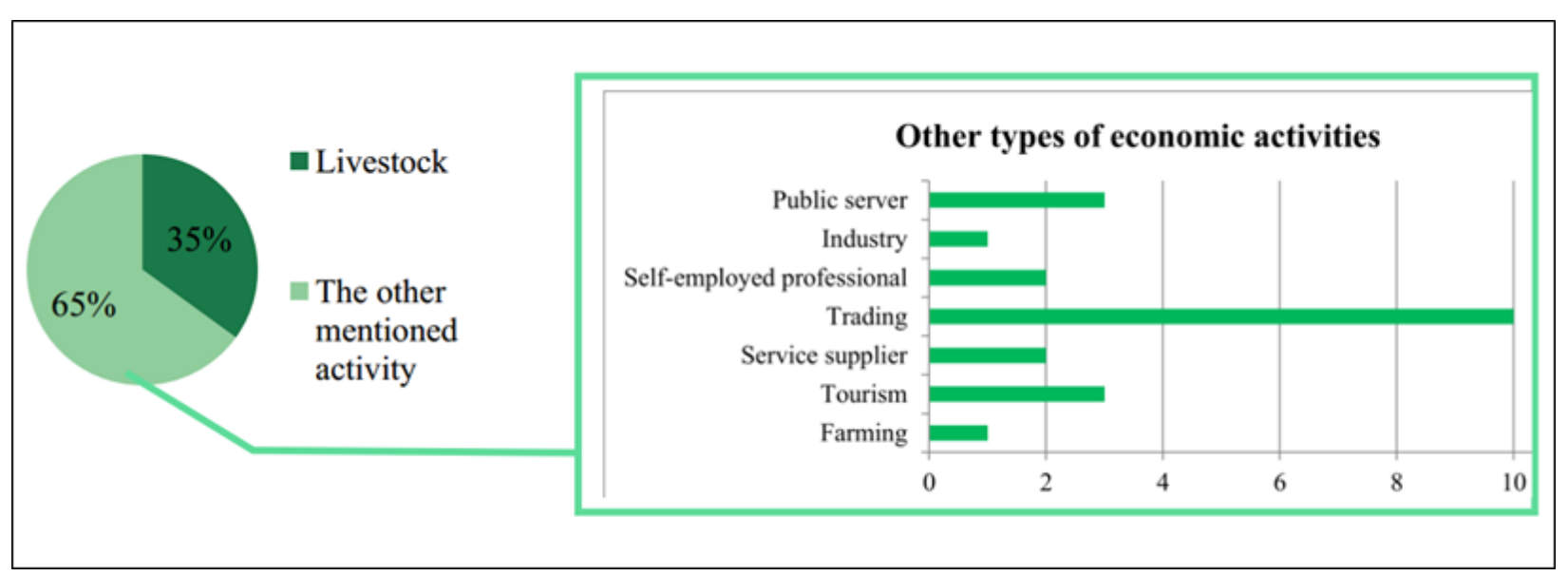

Figure 6. Graph: Which economic activity is your main activity: cattle raising or another? 
Data related to the cattlemen's age:

Table 2. Wetland cattlemen age groups

\begin{tabular}{|c|c|}
\hline Age Group & Quantity \\
\hline $30-40$ & 2 \\
\hline $40-50$ & 2 \\
\hline $50-60$ & 15 \\
\hline $60-70$ & 5 \\
\hline $70-80$ & 5 \\
\hline
\end{tabular}

Age is not an important variable in distinguishing those who defend wetland cattle raising as a primary economic activity from those who believe that it should be a complementary activity. This is likely to be related to the phase of family property fragmentation and the advance of urbanization in Poconé.

Table 3. Father's occupation

\begin{tabular}{|c|c|}
\hline Father's occupation & Proportion \\
\hline Cattlemen & $68,96 \%$ \\
\hline Non cattlemen & $31,03 \%$ \\
\hline
\end{tabular}

It is important to note that, among those whose fathers are not cattlemen, some have become cattlemen because their wives' fathers are cattlemen and they inherited the land.

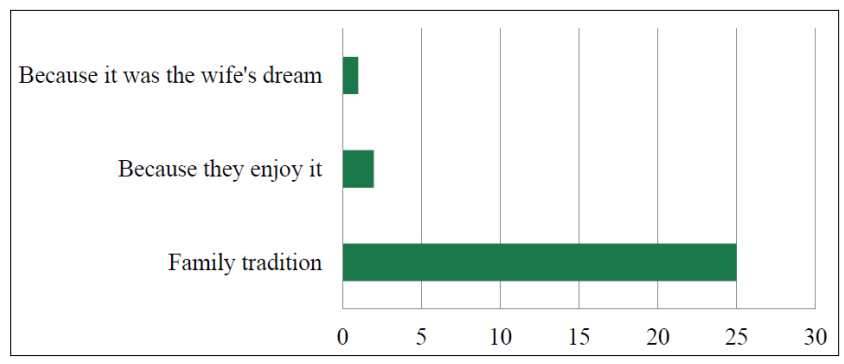

Figure 7. Graph: Reasons for having become cattlemen

In relation to schooling:

Table 4. Schooling of cattlemen in Poconé-MT

\begin{tabular}{|c|c|c|}
\hline Schooling level & Quantity & Percentage \\
\hline College Education & 16 & $55,17 \%$ \\
\hline High school & 13 & $44,83 \%$ \\
\hline
\end{tabular}

\section{Conclusions}

A visit to the city of Poconé can show the change in the social structure of the city's society. Cattlemen no longer enjoy the expression and symbol of power they used to in older times, the city tries to find other economic callings.

As for the data related to hypothesis 1 , Table 1 indicates that almost $80 \%$ of the wetland cattlemen do not live off cattle raising exclusively any longer, that is, they develop some other economic activity. Among those who live off cattle raising exclusively, some are retired from other activities and can now dedicate their time to the farm. These data do not take into account members of the family who chose another occupational status, sold their properties or left them to some brother to administrate.

According to the theory of cultural transmission, it would be interesting to investigate which choose the status of cattleman and which do not, so that we could better understand the mechanism of vertical socialization.

As far as the residence site is concerned, $86.2 \%$ live in the city of Poconé and the others live in Cuiabá, that is, cattlemen no longer live on the farm. The social dynamics of family property division is probably an important variable. The family production structure based on large properties and extensive cattle raising became unfeasible. The much smaller size of properties, the significant reduction in the size of herds and the lure exerted by the state capital city, $100 \mathrm{~km}$ from Poconé, in terms of educational and occupational opportunities probably made most of the cattlemen's children give up farm life. Graphs 2 and 3 offer clues to this. The wetland cattlemen themselves expressed, during the interviews, their concern in relation to the future of their properties, given that their children show no interest in them. They also agree that cattle raising in the Pantanal has become difficult economically speaking.

Children's help in the family production structure used to be critical, as they would take over the farm later on. We must take into consideration that among those who reported that their children did not help, some have small children who are unable to work in the farm. Among those who do help, three of them are veterinaries, that is, they engage in activities that are linked to farming. That is the reason why, even when they help, they also need to deal with their own activity outside the farm so it turns to be a matter of just helping. Figure 4 is not conclusive in this aspect; the concept of help must be more deeply explored and we need to understand what fathers consider help. This point was not explored during the interviews.

Comparing what the status of cattlemen used to be like when cattle raising was a primary economic activity, they lived on the farm, the children helped and were socialized in order to succeed them, changes have not favored the investment on the cattlemen status in the wetlands (Hypothesis 1).

In relation to the data for hypothesis 2 , Figure 5 indicates that $69 \%$ develop other economic activities, most of them urban activities. This shows that wetland cattlemen have become urban individuals, given that cattle raising is not the main activity of $69 \%$ of them. The classification per age groups shows that most of them are aged 50 and over, and, therefore, are not likely to invest in another occupational status.

Table 3 indicates that $70 \%$ of the cattlemen's fathers were cattlemen. Among those whose fathers were not cattlemen, the mother is a cattleman's daughter and she inherited the land. Therefore, the portion of cattlemen whose fathers were engaged in cattle raising is low. This information is consistent with Figure 7, which shows the reasons for 
becoming a cattleman, where $86.2 \%$ followed family tradition. The cattle raising economic activity was passed on from father to son almost as an assigned status.

Finally, Table 4 shows that $55.17 \%$ have a college degree, mostly programmers related to the area of agri-business, veterinary medicine, animal husbandry and agronomy. This indicates that, although it used to be basically an assigned status, individuals would prepare themselves since early and for a long period, which required training similar to that required by acquired occupational statuses.

Combining these with the data for hypothesis 1 , it seems sustainable to state that individuals choose the occupation of cattlemen as a complementary economic activity. In fact, it is still inherited, but now it will receive regular weekend investment from individuals. The situation is different from that experienced by their fathers and grandfathers, for whom the occupational status of a wetland cattleman was their main status and all other statuses revolved around it.

The changes we identified deserve being better investigated by means of complementary research focusing more precisely on the cattlemen's social family structure in order to understand why some children chose to invest in the cattleman occupation and others did not. In this sense, the theory of cultural transmission presents good indications.

\section{Acknowledgements}

This research is part of a larger study, funded by the Ministry of Science, Technology and Innovation and managed by the Pantanal Research Center (CPP), which mainly aims to produce knowledge for the sustainability of wetlands. Concerning this research, CPP requires the elaboration of a description of the occupational structure of cattlemen and anglers in the Pantanal.

\section{REFERENCES}

[1] Cavalli-Sforza, L.L.(2003). Genes, Povos e Línguas, SP: Cia das Letras.
[2] Cavalli-Sforza, L.L. and Feldman, M. (1973). Models for Cultural Inheritance I. Group Mean and Within Group Variation. Theoretical Population Biology 4, 42-55.

[3] Boyd, R., and Richerson, P., (1985). Culture and the Evolutionary Process. University of Chicago Press.

[4] Bisin, A. and Verdier, T. (1998). On the cultural transmission of preferences for social status. Journal of Public Economics (70), 75-97.

[5] Hopcroft, R.L. and Whitmeyer, J.M. (2010). A choice model of occupational status and fertility. Journal of Mathematical Sociology. 34: 283-300.

[6] Anderson, C. and Kilduff, G.F. (2009) The pursuit of status in social groups. Current Directions in Psychological Science, Volume 18, Number 5.

[7] Anderson, C. et al. (2012). The origins of deference: when do people prefer lower status? Journal of Personality and Social Psychology, V.12, N.5.

[8] Huberman, B. et al (2004). Status as a valued resource. Social Psychology Quarterly.Vol.67. N.1, 103-114.

[9] Barkow, J. (1989). Darwin, Sex and Status. Toronto: University of Toronto Press.

[10] Wright, R. (2000). O Animal Moral. Rio de Janeiro: Editora Campus.

[11] Blau, P. \& Duncan, O.D. (1967). The American Occupational Structure. New York: The Free Press.

[12] Vila da Silva, J.S. e Abdon, M.M. (1998). Delimitação do pantanal brasileiro e suas sub-regiões. Pesq. Agropec. Bras. Brasília, v.33. Número Especial: 1703-11.

[13] Martin, J. L. (2009). Social Structures. Princenton: Princenton University Press.

[14] Turner, J. H. (2000). Sociologia - conceitos e aplicações. São Paulo: Makron Books.

[15] Silva, C.J da \& Silva, J. A.F. (1995). No Ritmo das Águas do Pantanal. São Paulo: NUPAUB/USP. 